R. L. Hull • K. Kodama $\cdot$ K. M. Utzschneider •

D. B. Carr · R. L. Prigeon - S. E. Kahn

\title{
Dietary-fat-induced obesity in mice results in beta cell hyperplasia but not increased insulin release: evidence for specificity of impaired beta cell adaptation
}

Received: 18 August 2004 / Accepted: 12 February 2005 / Published online: 4 June 2005

(C) Springer-Verlag 2005

\begin{abstract}
Aims/hypothesis: Increased dietary fat intake is associated with obesity and insulin resistance, but studies have shown that the subsequent increase in insulin release is not appropriate for this obesity-induced insulin resistance. We therefore sought to determine whether the impaired beta cell adaptation is due to inadequate expansion of the beta cell population or to a lack of an adaptive increase in insulin release. Methods: Male mice were fed diets containing increasing amounts of fat $(15,30$ or $45 \%$ of energy intake) for 1 year, after which islet morphology and secretory function were assessed. Results: Increased dietary fat intake was associated with a progressive increase in body weight $(p<0.001)$. Fractional beta cell area (total beta cell area/section area) was increased with increasing dietary fat $(1.36 \pm 0.39,2.46 \pm 0.40$ and $4.93 \pm 1.05 \%$, $p<0.001$ ), due to beta cell hyperplasia, and was positively and highly correlated with body weight $\left(r^{2}=0.68, p<0.005\right)$. In contrast, insulin release following i.p. glucose did not increase with increasing dietary fat $(118 \pm 32,108 \pm 47$ and $488 \pm 200 \mathrm{pmol} / \mathrm{l}$ per $\mathrm{mmol} / \mathrm{l}, p=0.07)$ and did not correlate with body weight $\left(r^{2}=0.11\right)$. When this response was examined relative to fractional beta cell area (insulin release/fractional beta cell area), it did not increase but
\end{abstract}

R. L. Hull $(\bowtie) \cdot$ K. Kodama $\cdot$ K. M. Utzschneider · S. E. Kahn Division of Metabolism, Endocrinology and Nutrition, Department of Medicine, VA Puget Sound Health Care System (151), University of Washington,

1660 S. Columbian Way,

Seattle, WA, 98108, USA

e-mail: rhull@u.washington.edu

Tel.: +1-206-7642148

Fax: +1-206-2773011

D. B. Carr

Division of Maternal-Fetal Medicine, Department of Obstetrics and Gynecology, University of Washington, Seattle, WA, USA

R. L. Prigeon

Department of Medicine, Baltimore VA Medical Center, University of Maryland School of Medicine and Geriatric Research Education and Clinical Center,

Baltimore, MD, USA

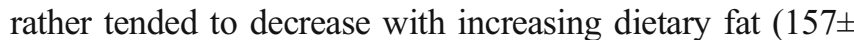
$55,43 \pm 13$ and $97 \pm 53[\mathrm{pmol} / \mathrm{l}$ per $\mathrm{mmol} / 1] / \%, p=0.06)$ and did not correlate with body weight $\left(r^{2}=0.02\right)$. Conclusions interpretation: Long-term fat feeding is associated with an increase in the beta cell population but an inadequate functional adaptation. Thus, a functional rather than a morphological abnormality appears to underlie dietaryfat-induced beta cell dysfunction.

Keywords Beta cell dysfunction - Beta cell mass · Dietary fat $\cdot$ Insulin secretion $\cdot$ Obesity

Abbreviations IRI: immunoreactive insulin - UCP2: uncoupling protein 2

\section{Introduction}

The incidence of obesity, the metabolic syndrome and type 2 diabetes is rapidly increasing worldwide [1,2]. The majority of individuals are able to adapt to obesity and the concurrent insulin resistance by adequately increasing insulin secretion [3, 4]. However, in those who are not able to adapt, the beta cell does not secrete sufficient insulin for the prevailing degree of insulin sensitivity, and glucose metabolism declines, leading eventually to type 2 diabetes. A contributing factor to the impaired beta cell function in individuals with impaired glucose tolerance and type 2 diabetes is likely to be the reduction in beta cell mass that has been demonstrated in both these states of reduced glucose tolerance [5-8].

While the susceptibility to beta cell dysfunction has a genetic component, environmental factors have clearly played a role in the exponential rise of type 2 diabetes and other metabolic abnormalities. One such environmental factor is increased dietary fat intake, which is associated with the development of obesity and insulin resistance [9, 10] and an increased rate of conversion from impaired glucose tolerance to type 2 diabetes [11]. Increased dietary fat intake in animals is also associated with the development of obesity and insulin resistance [12-14], and with 
decreased beta cell function [15]. The cause underlying this beta cell dysfunction is unclear, but two scenarios are possible. Firstly, the lack of appropriate expansion of beta cell mass, such as occurs in type 2 diabetes, may lead to beta cell dysfunction [5-8]. Alternatively, beta cell mass may expand appropriately, but a purely functional defect in the beta cell may underlie the cells' maladaptation to increased dietary fat. Several rodent studies have shown increased islet size in response to insulin resistance but many of these studies have utilised genetically manipulated mice or rats [16-20], making the findings more difficult to interpret and perhaps confounding interpretation of the processes underlying islet adaptation to obesity and insulin resistance.

In the present study, we sought therefore to determine the basis for impaired beta cell adaptation to obesity induced by long-term high-fat feeding. To do this, we fed three groups of normal mice different amounts of dietary fat for 1 year. We then examined beta cell adaptation in terms of (1) changes in islet morphology, including islet beta cell area, beta cell area per pancreas section area, beta cell size and the magnitude of beta cell replication and apoptosis, and (2) beta cell function in response to glucose stimulation.

\section{Materials and methods}

Animals Mice used in this study were bred in our colony at the Seattle Division of the VA Puget Sound Health Care System and were controls for a study examining the role of dietary fat in islet amyloid formation. As such, portions of the body weight and islet size data have been previously published [21]. At 6-8 weeks of age, male mice on a $\mathrm{C} 57 \mathrm{BL} / 6 \mathrm{~J} \times \mathrm{DBA} / 2 \mathrm{~J}$ hybrid background were randomly assigned to one of three dietary fat groups. Each group received a diet containing either $15 \%$ (low-fat, $n=7$ ), $30 \%$ (medium-fat, $n=7$ ) or $45 \%$ (high-fat, $n=8$ ) of energy intake derived from fat (Research Diets, Inc., New Brunswick, NJ, USA) for 1 year. The ratio of saturated : unsaturated fatty acids was 1:3 in all diets, and fat was derived from corn oil and hydrogenated coconut oil. The progressively increasing amounts of fat were balanced by decreasing amounts of carbohydrate $(65,50$ and $35 \mathrm{kcal} \%$ in low-, medium- and high-fat diets, respectively) and constant amounts of protein $(20 \mathrm{kcal} \%)$. Animals were followed on their respective diets for 1 year and were allowed free access to food and water unless otherwise stated. This study was approved by the Institutional Animal Care and Use Committee of the Seattle Division of the VA Puget Sound Health Care System.

Metabolic measurements Body weight was measured at the beginning and end of the study. After receiving the special diets for 1 year, mice underwent an overnight fast followed by a glucose load $(1 \mathrm{~g} / \mathrm{kg}$ dextrose i.p.) under pentobarbital anaesthesia $(100 \mathrm{mg} / \mathrm{kg}$ i.p.). Blood samples were drawn prior to and 15, 30, 60 and 120 min after glucose administration for determination of plasma glucose and immunoreactive insulin (IRI) concentrations. This test was performed on five mice in the low-fat group, five in the medium-fat group and eight in the high-fat group.

At killing, a portion of the pancreas (approximately 30 $\mathrm{mg}$ ) was snap frozen for homogenisation in isopropanol/ trifluoroacetic acid and subsequent measurement of pancreatic IRI content.

Plasma glucose was determined using a glucose oxidase method. Plasma levels and pancreatic content of IRI were measured by a modification of a previously described RIA $[22,23]$. Total protein for normalisation of pancreatic IRI content was assessed using a BCA kit (Pierce Biotechnology, Rockford, IL, USA).

Histological assessments At killing, pancreata were excised, fixed in $4 \%(\mathrm{w} / \mathrm{v})$ paraformaldehyde and embedded in paraffin. Five-micron serial sections were cut and stained with anti-insulin antibody (1:2,000; Sigma Chemical, St Louis, MO, USA) to visualise islet beta cells (Fig. 1), antiKi-67 antibody (1:50; DakoCytomation, Carpinteria, CA, USA) to detect replicating cells [24] or anti-activated caspase 3 antibody (1:100; Cell Signaling Technology, Beverly, MA, USA) to detect apoptotic cells [25]. Primary antibody binding was visualised with the appropriate secondary antisera conjugated to cy 3 (insulin staining for beta cell quantification and $\mathrm{Ki}-67$ and caspase 3 staining) or Alexa 488 (insulin staining for colocalisation with $\mathrm{Ki}-67$ or caspase 3). Sections used for beta cell area determinations
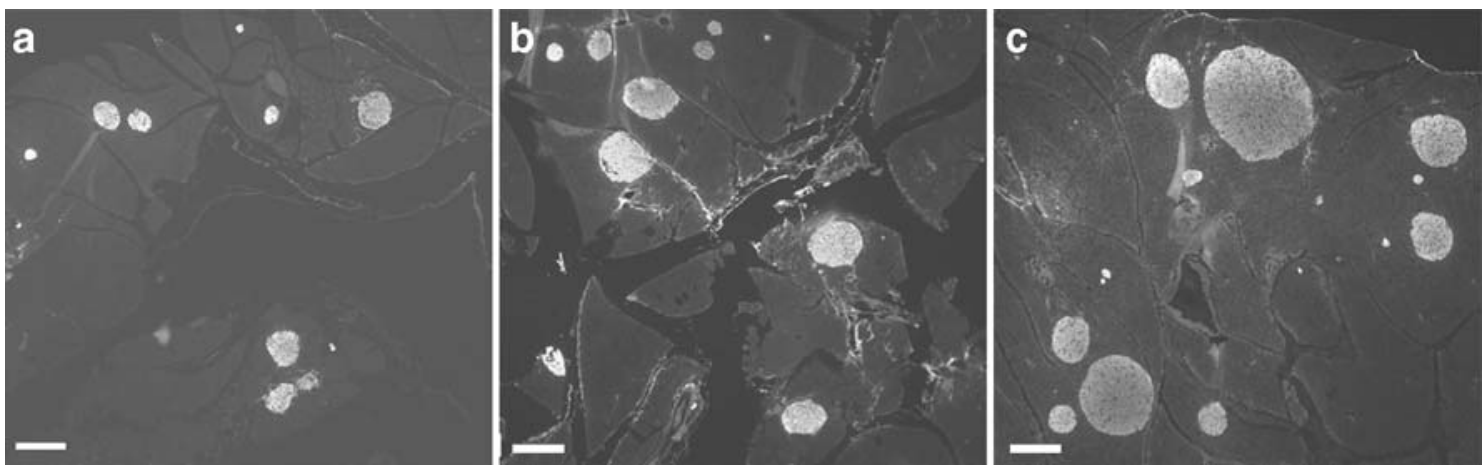

Fig. 1 Representative insulin immunostaining of pancreatic sections from mice fed a low- (15\% energy intake from fat, (a)), medium- (30\% energy intake from fat, (b)) or high- $(45 \%$ energy intake from fat, $(\mathbf{c}))$ fat diet for 1 year. Scale bar $=250 \mu \mathrm{m}$ 
were counterstained with thioflavin $\mathrm{S}$ to allow accurate determination of islet area. Sections used for beta cell size determination and replication and apoptosis measures were counterstained with the nuclear dye Hoechst $33258(2 \mu \mathrm{g} /$ $\mathrm{ml}$; Sigma) to visualise cell nuclei.

Histological assessments were made in all mice except for caspase 3, where two mice that received the mediumfat diet were excluded due to poor tissue morphology. Measurements were made on all islets present on sections representing three random portions of the pancreas (mean number islets scored per mouse $=17$ ). We have previously shown this sampling technique to be sufficiently representative of a whole mouse pancreas [26]. Due to technical limitations, double staining for insulin and Ki-67 or insulin and activated caspase 3 could not be achieved in all sections. Proportions of replicating or apoptotic cells were calculated per number of beta cells where possible (for replication: low-fat $n=3$, medium-fat $n=5$, high-fat $n=7$ and for apoptosis: low-fat $n=3$, medium-fat $n=3$ and highfat $n=8$ ) and compared with the replication and apoptosis proportions (per total islet cell number) in all mice. These measures were highly correlated both for Ki-67-positive cells $\left(r^{2}=0.83, p<0.0001\right)$ and for activated caspase 3positive cells $\left(r^{2}=0.99, p<0.0001\right)$. Thus, proportions of replicating and apoptotic cells are reported per islet cell.

Calculations and data analysis Islet area and beta cell area were computed as before [26]. Briefly, images for each islet were captured at $\times 200$ on each fluorescent channel. Islet area was demarcated with a video cursor on the thioflavin S channel (for beta cell area and beta cell size determinations) or on the Ki-67 or caspase 3 channel (for replication and apoptosis determinations) where the outline of the islet was clearly visible. The insulin-positive area within each islet area was then computed as fluorescence above a preset threshold. Section area was calculated for each mouse at low magnification $(\times 40)$. Mean islet area and mean islet beta cell area were then calculated for each mouse as the total islet area or islet beta cell area divided by the number of islets scored. Fractional beta cell area was determined as a surrogate measure for beta cell mass and was computed as total beta cell area/section area $\times 100 \%$. Islet density was computed as the number of islets per square millimetre section area.

Mean beta cell size and mean number of beta cells per islet were calculated for each dietary group using nuclear staining. Beta cell size was determined in a subsection of each islet corresponding only to insulin-positive staining. With the video cursor an area was demarcated that excluded blood vessels, non-beta endocrine cells or other non-beta cells. The number of beta cells within this area was then computed as follows. The average size of a single nucleus was first quantified in each insulin-positive area at $\times 200$ magnification. The requirement for a single nucleus was an area of Hoechst-positive fluorescence above a preset threshold, between 7 and $50 \mu \mathrm{m}^{2}$ in size and approximately circular in shape. This parameter was calculated for a total of 365 islets $(9,762$ cells), with an average value of $24.9 \mu \mathrm{m}^{2}$ (range 15.6-28.6 $\mathrm{m}^{2}$ ). The area of a single nucleus did not vary among dietary groups $\left(24.5 \pm 0.6,24.9 \pm 1.9,25.1 \pm 0.9 \mu^{2}\right.$ for low-, medium- and high-fat-fed animals, respectively) and did not change with islet size $\left(r^{2}=0.05\right.$ for correlation between single nuclear area and islet area). The total nuclear area within the insulin-positive area was then calculated as the total area corresponding to Hoechst-positive fluorescence above the same preset threshold. Intra- and inter-observer $\mathrm{CV}$ values for these measurements in our hands were 13 and $4 \%$, respectively. The number of beta cells within the insulinpositive area was then derived as total nuclear area per islet/ average single nuclear area. Finally, mean beta cell was calculated as insulin-positive area/number of beta cells. This parameter was computed in all mice, in an average of 1,672 beta cells per mouse. The number of beta cells per islet was quantified in all islets using the same approach as above, with the demarcated area corresponding to the whole islet area to first derive the number of cells per islet. The number of cells per islet was then multiplied by the proportion of insulin-positive staining per islet to derive the number of beta cells per islet.

The rates of replication and apoptosis were quantified as (number of Ki-67- or activated caspase-3-positive islet cells, respectively/total number of islet cells assessed per section) $\times 100 \%$.

The incremental insulin response following i.p. glucose was calculated by subtracting the fasting IRI level (time 0 ) from the IRI level $30 \mathrm{~min}$ following glucose administration and dividing this number by the change in glucose concentration over the same time period.

Data are expressed as means \pm SEM. Comparisons between the three dietary groups were performed using the Jonckheere-Terpstra non-parametric test for ordinal variables, a test that takes into account the dose effect of increasing dietary fat [27]. Plasma glucose and insulin levels following i.p. glucose administration were analysed by the general linear model for repeated measures (SPSS, Inc., Chicago, IL, USA). Correlation analyses were performed using simple linear regression. A $p \leq 0.05$ was considered significant.

\section{Results}

Body weight Body weight was comparable among groups at the beginning of the study and increased progressively with increasing dietary fat at the end of the 1-year study (Table 1).

Table 1 Body weight and weight gain in male mice fed diets containing low, medium and high fat for 1 year

\begin{tabular}{lllll}
\hline & \multicolumn{2}{l}{ Dietary fat } & \multirow{2}{*}{$p$} \\
\cline { 2 - 4 } & Low & Medium & High & \\
\hline Initial body weight $(\mathrm{g})$ & $31.9 \pm 4.2$ & $28.0 \pm 0.3$ & $28.6 \pm 2.1$ & 0.38 \\
Final body weight $(\mathrm{g})$ & $46.5 \pm 2.0$ & $51.1 \pm 2.2$ & $60.3 \pm 1.9$ & 0.001 \\
\hline
\end{tabular}


Morphological changes in response to dietary fat Increasing dietary fat was associated with a dose-dependent increase in both mean islet beta cell area (Figs. 1 and 2a) and fractional beta cell area (Figs. 1 and $2 b$ ). Both measures of beta cell area were strongly correlated with body weight (Fig. 2c,d). Increased islet number did not contribute to the observed increase in fractional beta cell area, as islet density was not different among dietary groups $\left(1.46 \pm 0.19,1.22 \pm 0.21\right.$ and $1.72 \pm 0.14$ islets $\left./ \mathrm{mm}^{2}\right)$. Mean islet area also increased with increasing dietary fat (low-, medium- and high-fat: $24,419 \pm 3,732,45,811 \pm 9,230$ and $\left.59,142 \pm 8,220 \mu \mathrm{m}^{2}, p<0.0001\right)$ and was correlated with body weight $\left(r^{2}=0.38, p<0.0001\right)$, such that the proportion of beta cell area occupying islet area did not change among groups $(73.2 \pm 1.1,74.5 \pm 1.7$ and $74.4 \pm 2.0 \%$, respectively).

In order to determine whether the increased islet size seen with increasing dietary fat was due to islet cell hyperplasia or hypertrophy, mean islet beta cell number and mean beta cell size were calculated for each dietary group. Increasing dietary fat was associated with a significant increase in the mean number of beta cells per islet (Fig. 3a), which was strongly correlated with body weight $\left(r^{2}=0.47, p<0.0001\right)$. Consequently, mean beta cell size did not change with increasing dietary fat (Fig. 3b) and was not correlated with body weight $\left(r^{2}=0.015\right)$.

Beta cell turnover in response to increased dietary fat $\mathrm{We}$ next determined whether the increase in islet beta cell area was associated with increased replication, decreased apoptosis or both after 1 year of dietary feeding. The percentage of Ki-67-positive cells relative to the total number of islet cells was not significantly different among dietary groups $(0.12 \pm 0.04,0.29 \pm 0.07$ and $0.17 \pm 0.03 \%)$ and was not correlated with body weight $\left(r^{2}=0.04\right)$. However, the percentage of $\mathrm{Ki}-67$-positive islet cells increased with increasing mean islet beta cell area $\left(r^{2}=0.20, p<0.05\right)$. In contrast, the percentage of activated caspase-3-positive islet cells did not change with increasing dietary fat $(0.72 \pm 0.21$, $0.58 \pm 0.20$ and $0.55 \pm 0.16 \%$ ) and this measure of cell death did not correlate with body weight $\left(r^{2}=0.04\right)$ or mean islet beta cell area $\left(r^{2}=0.08\right)$.

Pancreatic insulin content Pancreatic insulin content was

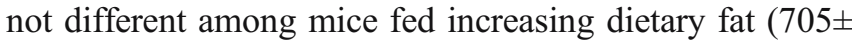
$220,489 \pm 146$ and $1,190 \pm 273 \mathrm{pmol} / \mathrm{mg}$ protein), although pancreatic insulin content was positively correlated with body weight $\left(r^{2}=0.23, p<0.05\right)$, islet size $\left(r^{2}=0.34, p<\right.$ $0.01)$ and beta cell area $\left(r^{2}=0.40, p<0.005\right)$.

Functional changes in response to dietary fat Intake of increasing dietary fat for 1 year was associated with no change in fasting plasma glucose levels $(6.0 \pm 0.3,6.8 \pm 1.1$ and $6.6 \pm 0.3 \mathrm{mmol} / 1$ for the low-, medium- and high-fatfed mice, respectively, Fig. 4a) but an increase in fasting plasma insulin levels $(124 \pm 73,523 \pm 275$ and $713 \pm 267$ pmol $/ 1, p<0.005$, Fig. 4b). Fasting plasma insulin was positively correlated with body weight $\left(r^{2}=0.26, p<0.05\right)$. Following i.p. glucose administration, plasma glucose levels were not different among groups (Fig. 4a), while plasma insulin levels progressively increased with increasing dietary fat $(p<0.05$, Fig. $4 \mathrm{~b})$.

Glucose-stimulated insulin secretion was calculated as the incremental insulin response $30 \mathrm{~min}$ after glucose administration, when insulin and glucose levels were max-
Fig. 2 Mean islet beta cell area (a) and fractional beta cell area (b) in mice fed low- $(15 \%$ energy intake from fat), medium- $(30 \%$ energy intake from fat) and high- (45\% energy intake from fat) fat diets for 1 year. Correlations are shown between mean islet beta cell area (c) and fractional beta cell area (d) and body weight. Mice fed low-, medium- and high-fat diets are shown in circles, triangles and squares, respectively. Increased dietary fat was associated with increased islet beta cell area $(p<0.0001)$ and fractional beta cell area $(p<0.0001)$, with both measures being positively correlated with body weight $\left(r^{2}=0.39, p<0.005\right.$ for islet beta cell area and $r^{2}=0.68, p<0.0001$ for fractional beta cell area) a

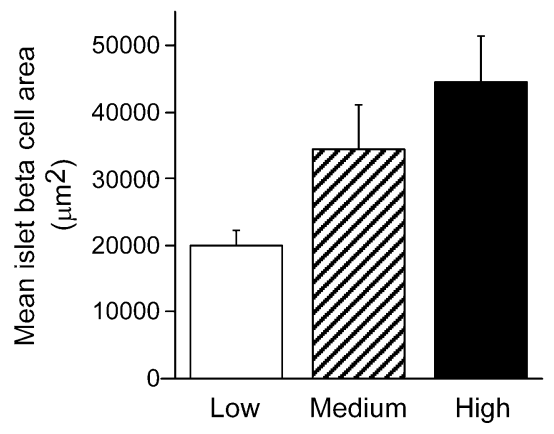

C

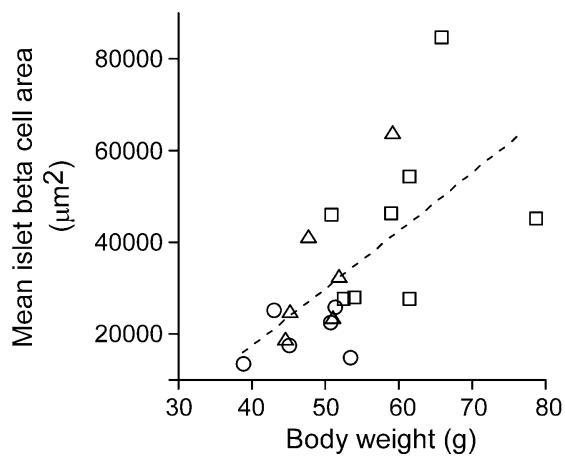

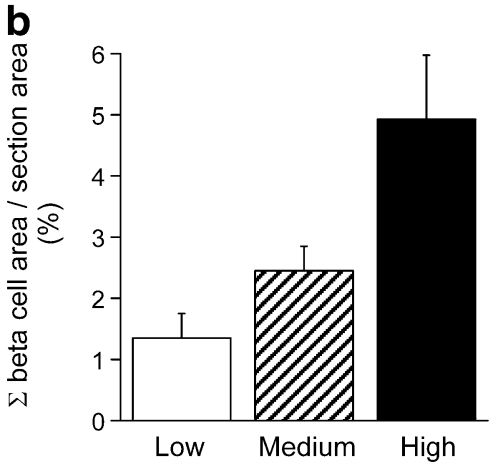

d

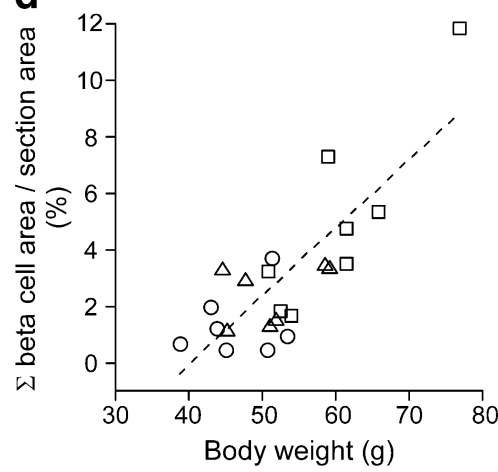


Fig. 3 Mean number of beta cells per islet (a) and mean beta cell size (b) in mice fed low( $15 \%$ energy intake from fat), medium- $30 \%$ energy intake from fat) and high- ( $45 \%$ energy intake from fat) fat diets for 1 year. The number of beta cells per islet increased with increased dietary fat $(p<0.01)$. In contrast there was no change in mean beta cell size among dietary groups a

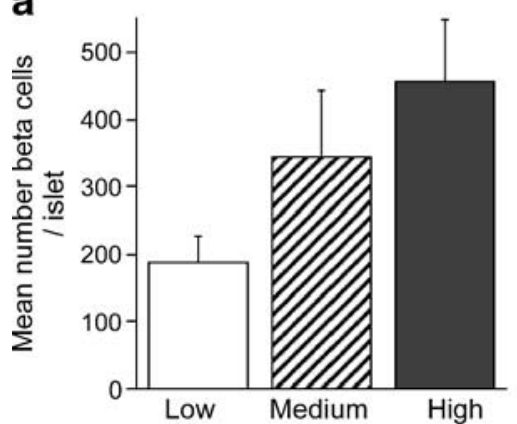

b

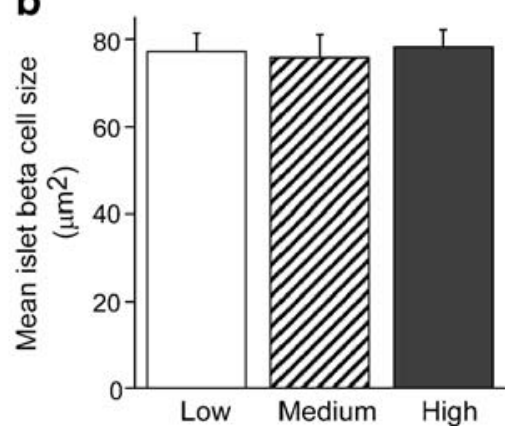

imal, divided by the change in glucose over the same time period $\left(\Delta I_{0-30} / \Delta G_{0-30}\right)$. Unexpectedly, insulin secretion was not different among dietary groups $(p=0.07$, Fig. $5 \mathrm{a})$, and this measure did not correlate with body weight (Fig. $5 c)$. When insulin secretion was expressed per unit of fractional beta cell area, rather than increasing, insulin secretion tended to decrease with increasing dietary fat $(p=0.06$, Fig. $5 b)$. This measure of beta cell function also did not correlate with body weight (Fig. 5d).
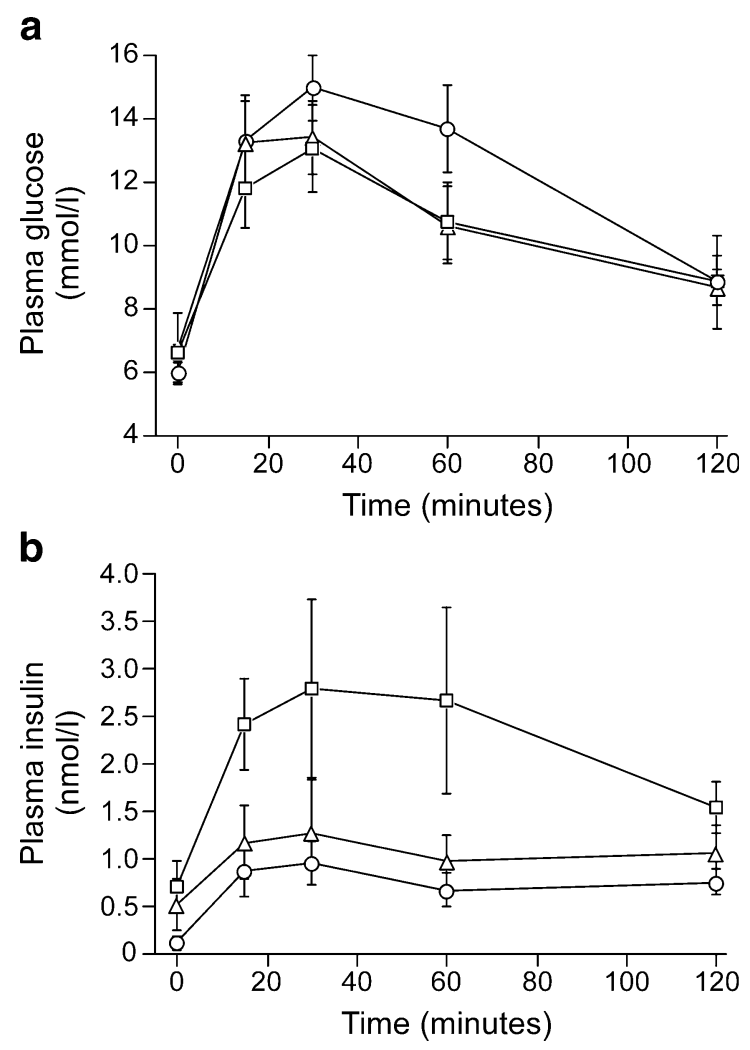

Fig. 4 Plasma glucose (a) and immunoreactive insulin (b) levels before and after i.p. glucose $(1 \mathrm{~g} / \mathrm{kg})$ in mice fed low- $(15 \%$ energy intake from fat; circles), medium- (30\% energy intake from fat; triangles) and high- (45\% energy intake from fat; squares) fat diets for 1 year. Fasting plasma glucose was similar among groups, while fasting plasma insulin increased significantly with increasing dietary fat $(p<0.005)$. After i.p. glucose administration, plasma glucose levels were not different among groups over time, while plasma insulin levels increased progressively with increasing dietary fat $(p<0.05)$, consistent with increasing secretory demand due to obesity and insulin resistance

\section{Discussion}

In our model of long-term fat feeding, we have shown that mice adapt to diet-induced obesity by increasing their islet beta cell mass in proportion to body weight. This expansion of the beta cell population occurs through hyperplasia rather than hypertrophy. In contrast, insulin release in response to glucose did not increase in proportion to obesity or the increase in fractional beta cell area. Our data suggest that the beta cell dysfunction seen with increasing dietary fat is largely a functional, rather than a morphological abnormality.

Several studies have reported increased islet size with obesity in rodents, with many of these utilising genetic models of obesity [16-20]. The increase in mean islet size that we observed with 1 year of high-fat feeding was approximately twofold as compared with that in the low-fatfed group, in line with reports of the difference in mean islet size observed when comparing obese and lean humans [8]. Of note is the fact that the increase in islet size seen in the present study is markedly less than the increases (up to ninefold) in islet size seen with some genetically modified rodent models of obesity and/or diabetes [16-20]. While in some cases, the change in islet size in these genetically modified mice was comparable with that seen in the present study $[16,17,20]$, these studies were performed over much shorter time periods than 1 year, and are thus more consistent with a marked increase in the rate of islet size expansion often seen with genetically modified rodent models. Thus, we believe the current long-term high-fat-fed model may provide important insight into islet adaptation to obesity in the absence of potentially confounding effects of genetic mutations.

Our finding that the dietary-fat-induced increase in beta cell area results from hyperplasia rather than hypertrophy is, to the best of our knowledge, the first description of the mechanism for the increased islet size in diet-induced obesity. Beta cell replication, expressed as the percentage of Ki-67-positive cells, was positively correlated with islet size and beta cell area. In contrast, no difference in beta cell apoptosis was seen among animals fed the different fat diets, suggesting that in this model increased dietary fat feeding and the resulting obesity is not associated with increased beta cell death. These data are consistent with a greater drive to increase islet mass in the mice with the larger beta cell areas, due to the increased secretory de- 
Fig. 5 Insulin secretion in response to i.p. glucose in mice fed low- $(15 \%$ energy intake from fat), medium- (30\% energy intake from fat) or high- (45\% energy intake from fat) fat diets for 1 year. Insulin response $\left(\Delta I_{0}\right.$ $\left.{ }_{-30} / \Delta G_{0-30}\right)$ is shown unadjusted (a) and expressed per unit of fractional beta cell area (b). Correlation analyses between insulin response (c) or insulin response per fractional beta cell area (d) and body weight are shown. Mice fed low-, mediumand high-fat diets are shown in circles, triangles and squares, respectively. The data indicate that the insulin response did not significantly increase with increasing dietary fat $(p=0.07)$ and did not significantly decrease when assessed relative to fractional beta cell area $(p=0.06)$. No correlation was observed between either measure and body weight $\left(r^{2}=0.11\right.$ and $r^{2}=0.02$, respectively) a

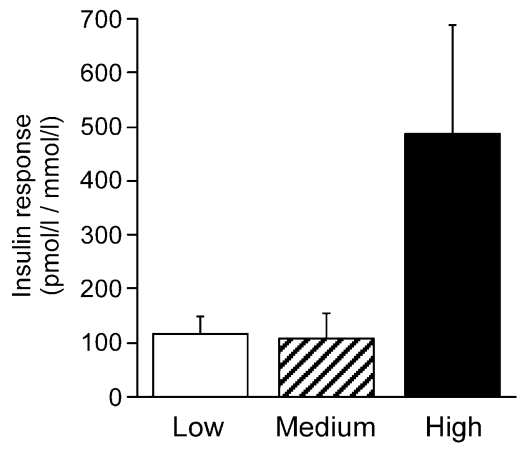

C

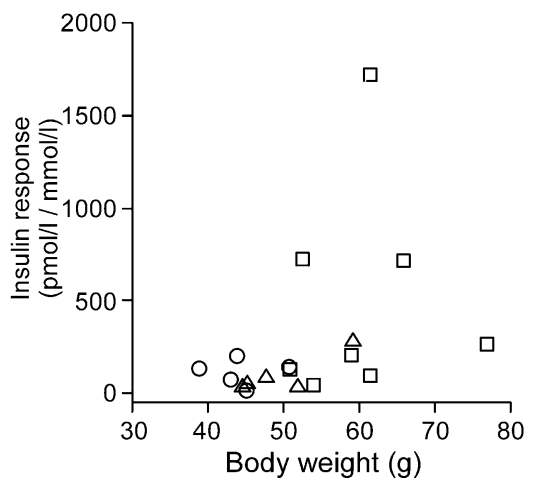

b

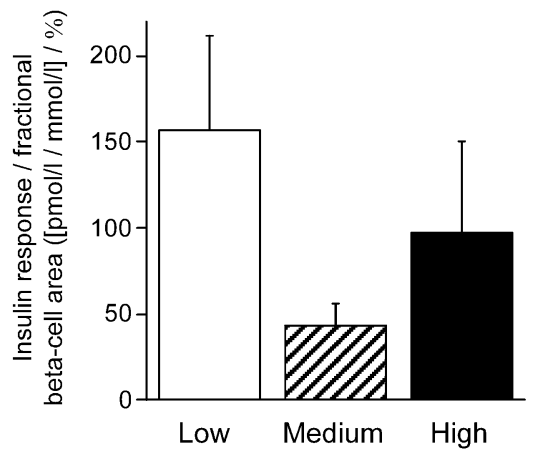

d

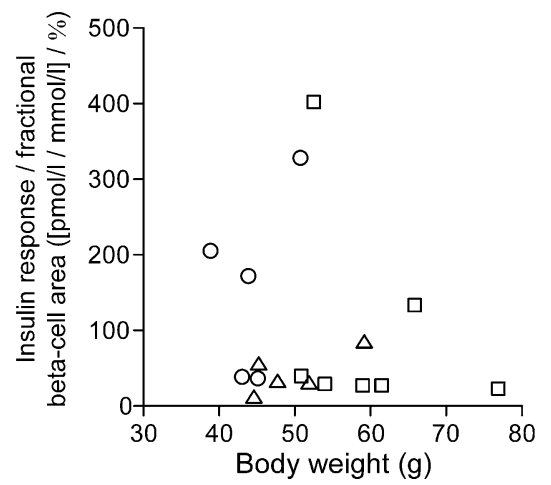

mand resulting from diet-induced obesity and insulin resistance.

Factors contributing to the increased beta cell area that we observed with increasing dietary fat intake might include a direct effect of glucose and/or NEFAs. Glucose infusions (up to 4 days) in rats result in increased beta cell mass, arising by both beta cell hyperplasia and hypertrophy, together with a concomitant increase in glucose-stimulated insulin secretion [28-30]. Increased plasma glucose levels were not observed either following 1 year of increased dietary fat feeding, or when 4-h fasting glucose levels were assessed during the study (data not shown), making glucose an unlikely mediator of the observed increase in islet mass. In contrast, lipid infusion has been shown to result in increased beta cell mass, due to beta cell proliferation, with no concomitant improvement in insulin release during a hyperglycaemic clamp [29]. This is consistent with a disconnection in the regulation of beta cell mass and secretory function in the presence of increased NEFA. Such a change may have played a role in the increased islet mass we report here, although we cannot be sure, as unfortunately we do not have NEFA measurements. However, several studies have shown increased plasma NEFA with high-fat feeding in mice [31-34].

Despite the morphological changes that we observed with dietary-fat-induced obesity in these mice, we observed functional changes that were opposite to what would be predicted to occur during adequate adaptation. In order for the beta cell to compensate sufficiently for obesity and insulin resistance and maintain euglycaemia, insulin secretion must increase. Our data show that the increase in insulin secretion following i.p. glucose in the high-fat-fed mice did not correlate with body weight. When normalised to fractional beta cell area, insulin release tended to decrease with increasing dietary fat. While this decrease in insulin release relative to fractional beta cell area did not reach statistical significance $(p=0.06)$, we believe this is a function of the number of animals in the present study. In keeping with this trend, insulin release relative to fractional beta cell area also did not correlate with body weight. Thus, while increasing dietary fat is associated with an increase in fractional beta cell area that is proportional to the increase in body weight, insulin release does not increase in proportion to obesity. These observations are consistent with adaptation to dietary-fat-induced obesity comprising an increased number of beta cells that, as a population, are less functional. This relative decrease in insulin release was not sufficient to cause glucose intolerance in the present study. Increased insulin-independent glucose disposal probably contributed to the maintenance of euglycaemia in our mice, since this is a major pathway for glucose disposal in mice [35]. This lack of increased secretion is unlikely to be caused by inadequate biosynthesis or degranulation of the beta cells, as pancreatic insulin content increased in proportion to increased body weight and islet beta cell area. Thus, it would appear that increased fat intake and the associated obesity results in an inability to increase stimulus-secretion coupling.

The lack of adaptation of the insulin response in the present study is in line with the findings of Kaiyala et al. [15], who found that high-fat feeding for 7 weeks in dogs was associated with a $57 \%$ decrease in insulin sensitivity with no compensatory increase in the acute insulin response to glucose. As a result, based on the known hyperbolic relationship between insulin sensitivity and the insulin response that they showed also existed in dogs, this 
failure to increase the insulin response was reflected as a $59 \%$ decrease in beta cell function. The findings of our study and those of Kaiyala et al. are in keeping with those of others [36] and suggest that dietary fat may have a direct, adverse effect on the secretory function of the islet beta cell. Such a negative effect has been demonstrated by the presence of impaired glucose-stimulated insulin secretion in perifused islets isolated from mice fed a high-fat diet for 4 months [37]. Furthermore, in vivo and in vitro studies in humans and rodents have shown that prolonged elevation of NEFAs leads to impaired glucose-stimulated insulin secretion, impaired proinsulin processing and inhibition of insulin biosynthesis [38-42]. While the mechanism(s) underlying the cause of dietary-fat-induced beta cell dysfunction is (are) unclear, increased intra-islet triglyceride accumulation may be a contributor [43, 44], leading to increased triglyceride mobilisation by hormone-sensitive lipase [45], upregulation of the mitochondrial uncoupling protein 2 (UCP2) [46] and impaired insulin secretion [47, 48]. Consistent with a role for lipid accumulation in beta cell dysfunction, interventions that reduce accumulation and mobilisation of intra-beta cell triglyceride and/or decrease islet UCP2 levels have been associated with improved beta cell secretory function [49-51].

In type 2 diabetes, reduced beta cell function is seen and beta cell mass is decreased by as much as $50 \%$ [6-8]; however, since longitudinal measures of beta cell mass have not been made in humans, no cause and effect relationship can be determined. It is important to note that this decrease in beta cell mass must be compared with an appropriate non-diabetic control group, since islet mass changes in response to obesity and insulin resistance in humans as it does in mice. Thus, studies such as the recent one by Butler et al. [8] showed that obesity is associated with increased fractional beta cell area in humans but that individuals with type 2 diabetes, when correctly matched to either lean or obese controls, display a significant decrease in fractional beta cell area. However, decreased beta cell mass is not likely to be the simple explanation for the development of hyperglycaemia if there is no genetic predisposition to impaired beta cell function. Pancreatectomy studies in rats have shown that $90 \%$ of the pancreas (and thus beta cell mass) must be removed in order for glucose levels to increase [52]. In keeping with this observation, it has been demonstrated that functional adaptation of beta cells involving an enhancement of the beta cell's sensitivity to glucose is sufficient to maintain euglycaemia following a $65 \%$ pancreatectomy in dogs [53]. Thus, it appears that while decreased beta cell mass is an important contributor, it is unlikely to be the sole cause of beta cell dysfunction in type 2 diabetes. In the present study we have shown that incomplete functional adaptation can occur even in the face of an increase in the beta cell population, clearly suggesting that beta cell mass and function are not always coordinately regulated.

In summary, we found that feeding mice increased dietary fat for 1 year is associated with an increase in the beta cell population as a result of hyperplasia and that this increase is proportional to body weight. In contrast, glucose-stimulated insulin release did not increase in proportion to body weight or fractional beta cell area, suggesting the development of a specific functional impairment caused by dietary fat. Based on these findings it would appear that secretory dysfunction of beta cells arising from increased dietary fat could be an important contributing factor to decreased beta cell function in obese, insulin-resistant individuals and, in those who are genetically susceptible, could also contribute to the increased rate of conversion from impaired glucose tolerance to type 2 diabetes [11].

Acknowledgements We thank Maggie Abrahamson, Robin Vogel, Jira Wade, Ruth Hollingworth, Yuli McCutchen, Caj Fernstrom and Rebekah Koltz for excellent technical support. This work was supported by the Medical Research Service of the Department of Veterans Affairs, NIH grants DK-17047 and DK-50703 and the American Diabetes Association. R. L. Hull was supported by a Juvenile Diabetes Foundation Fellowship. K. Kodama was supported by the Manpei Suzuki International Diabetes Foundation. K. M. Utschneider was supported by NIH training grant HL-07028. D. B. Carr was supported by NIH grant RR16066. R. L. Prigeon was supported by GRECC, Baltimore VA Medical Center.

\section{References}

1. Mokdad AH, Bowman BA, Ford ES, Vinicor F, Marks JS, Koplan JP (2001) The continuing epidemic of obesity and diabetes in the United States. JAMA 286:1195-1200

2. Ford ES, Giles WH, Dietz WH (2002) Prevalence of the metabolic syndrome among US adults: findings from the third National Health and Nutrition Examination Survey. JAMA 287:356-359

3. Bergman RN, Phillips LS, Cobelli C (1981) Physiologic evaluation of factors controlling glucose tolerance in man: measurement of insulin sensitivity and beta-cell glucose sensitivity from the response to intravenous glucose. J Clin Invest 68:1456-1467

4. Kahn SE, Prigeon RL, McCulloch DK et al (1993) Quantification of the relationship between insulin sensitivity and beta-cell function in human subjects. Evidence for a hyperbolic function. Diabetes 42:1663-1672

5. Westermark P (1972) Quantitative studies on amyloid in the islets of Langerhans. Ups J Med Sci 77:91-94

6. Kloppel G, Lohr M, Habich K, Oberholzer M, Heitz PU (1985) Islet pathology and the pathogenesis of type 1 and type 2 diabetes mellitus revisited. Surv Synth Pathol Res 4:110-125

7. Clark A, Wells CA, Buley ID et al (1988) Islet amyloid, increased A-cells, reduced B-cells and exocrine fibrosisquantitative changes in the pancreas in type-2 diabetes. Diab Res Clin Exp 9:151-159

8. Butler AE, Janson J, Bonner-Weir S, Ritzel R, Rizza RA, Butler PC (2003) Beta-cell deficit and increased beta-cell apoptosis in humans with type 2 diabetes. Diabetes 52:102-110

9. Reaven GM (1988) Banting Lecture 1988. Role of insulin resistance in human disease. Diabetes 37:1595-1607

10. Pi-Sunyer FX (1993) Medical hazards of obesity. Ann Intern Med 119:655-660

11. Marshall JA, Hoag S, Shetterly S, Hamman RF (1994) Dietary fat predicts conversion from impaired glucose tolerance to NIDDM. The San Luis Valley Diabetes Study. Diabetes Care 17:50-56

12. Storlien LH, James DE, Burleigh KM, Chisholm DJ, Kraegen EW (1986) Fat feeding causes widespread in vivo insulin resistance, decreased energy expenditure, and obesity in rats. Am J Physiol 251:E576-E583 
13. Storlien LH, Jenkins AB, Chisholm DJ, Pascoe WS, Khouri S, Kraegen EW (1991) Influence of dietary fat composition on development of insulin resistance in rats. Relationship to muscle triglyceride and omega-3 fatty acids in muscle phospholipid. Diabetes 40:280-289

14. Rocchini AP, Marker P, Cervenka T (1997) Time course of insulin resistance associated with feeding dogs a high-fat diet. Am J Physiol 272:E147-E154

15. Kaiyala KJ, Prigeon RL, Kahn SE, Woods SC, Porte D Jr, Schwartz MW (1999) Reduced beta-cell function contributes to impaired glucose tolerance in dogs made obese by high-fat feeding. Am J Physiol 277:E659-E667

16. Garcia-Ocana A, Takane KK, Syed MA, Philbrick WM, Vasavada RC, Stewart AF (2000) Hepatocyte growth factor overexpression in the islet of transgenic mice increases beta cell proliferation, enhances islet mass, and induces mild hypoglycemia. J Biol Chem 275:1226-1232

17. Ludwig DS, Tritos NA, Mastaitis JW et al (2001) Melaninconcentrating hormone overexpression in transgenic mice leads to obesity and insulin resistance. J Clin Invest 107:379-386

18. Bernal-Mizrachi E, Wen W, Stahlhut S, Welling CM, Permutt MA (2001) Islet beta cell expression of constitutively active Akt1/PKB alpha induces striking hypertrophy, hyperplasia, and hyperinsulinemia. J Clin Invest 108:1631-1638

19. Butler AE, Janson J, Soeller WC, Butler PC (2003) Increased beta-cell apoptosis prevents adaptive increase in beta-cell mass in mouse model of type 2 diabetes: evidence for role of islet amyloid formation rather than direct action of amyloid. Diabetes 52:2304-2314

20. Bock T, Pakkenberg B, Buschard K (2003) Increased islet volume but unchanged islet number in $o b / o b$ mice. Diabetes 52:1716-1722

21. Hull RL, Andrikopoulos S, Verchere CB et al (2003) Increased dietary fat promotes islet amyloid formation and $\beta$-cell secretory dysfunction in a transgenic mouse model of islet amyloid. Diabetes 52:372-379

22. Morgan DR, Lazarow A (1963) Immunoassay of insulin: two antibody system: plasma insulin levels of normal, subdiabetic, and diabetic rats. Diabetes 12:115-126

23. Andrikopoulos S, Verchere CB, Terauchi Y, Kadowaki T, Kahn SE (2000) Beta-cell glucokinase deficiency and hyperglycemia are associated with reduced islet amyloid deposition in a mouse model of type 2 diabetes. Diabetes 49:2056-2062

24. Scholzen T, Gerdes J (2000) The Ki-67 protein: from the known and the unknown. J Cell Physiol 182:311-322

25. Olney JW, Tenkova T, Dikranian K, Qin YQ, Labruyere J, Ikonomidou C (2002) Ethanol-induced apoptotic neurodegeneration in the developing C57BL/6 mouse brain. Brain Res Dev Brain Res 133:115-126

26. Wang F, Hull RL, Vidal J, Cnop M, Kahn SE (2001) Islet amyloid develops diffusely throughout the pancreas before becoming severe and replacing endocrine cells. Diabetes 50:2514-2520

27. Jonckheere AR (1954) A distribution-free $k$-sample test against ordered alternatives. Biometrika 41:133-145

28. Bonner-Weir S, Deery D, Leahy JL, Weir GC (1989) Compensatory growth of pancreatic beta-cells in adult rats after short-term glucose infusion. Diabetes 38:49-53

29. Steil GM, Trivedi N, Jonas JC et al (2001) Adaptation of betacell mass to substrate oversupply: enhanced function with normal gene expression. Am J Physiol Endocrinol Metab 280: E788-E796

30. Woerner CA (1939) Studies on the islands of Langerhans after continuous injection of dextrose. Anat Rec 71:22-57

31. Ahren B, Simonsson E, Scheurink AJ, Mulder H, Myrsen U, Sundler F (1997) Dissociated insulinotropic sensitivity to glucose and carbachol in high-fat diet-induced insulin resistance in C57BL/6J mice. Metabolism 46:97-106

32. Ahren B, Scheurink AJ (1998) Marked hyperleptinemia after high-fat diet associated with severe glucose intolerance in mice. Eur J Endocrinol 139:461-467
33. Mulder H, Martensson H, Sundler F, Ahrén B (2000) Differential changes in islet amyloid polypeptide (amylin) and insulin mRNA expression after high-fat diet-induced insulin resistance in C57BL/6J mice. Metabolism 49:1518-1522

34. Burcelin R, Crivelli V, Dacosta A, Roy-Tirelli A, Thorens B (2002) Heterogeneous metabolic adaptation of C57BL/6J mice to high-fat diet. Am J Physiol Endocrinol Metab 282:E834 E842

35. Pacini G, Thomaseth K, Ahrén B (2001) Contribution to glucose tolerance of insulin-independent vs. insulin-dependent mechanisms in mice. Am J Physiol Endocrinol Metab 281: E693-E703

36. Ahren B, Pacini G (2002) Insufficient islet compensation to insulin resistance vs. reduced glucose effectiveness in glucoseintolerant mice. Am J Physiol Endocrinol Metab 283:E738E744

37. Lee SK, Opara EC, Surwit RS, Feinglos MN, Akwari OE (1995) Defective glucose-stimulated insulin release from perifused islets of C57BL/6J mice. Pancreas 11:206-211

38. Zhou YP, Grill VE (1994) Long-term exposure of rat pancreatic islets to fatty acids inhibits glucose-induced insulin secretion and biosynthesis through a glucose fatty acid cycle. J Clin Invest 93:870-876

39. Bollheimer LC, Skelly RH, Chester MW, McGarry JD, Rhodes CJ (1998) Chronic exposure to free fatty acid reduces pancreatic beta cell insulin content by increasing basal insulin secretion that is not compensated for by a corresponding increase in proinsulin biosynthesis translation. J Clin Invest 101:1094-1101

40. Bjorklund A, Grill V (1999) Enhancing effects of long-term elevated glucose and palmitate on stored and secreted proinsulin-to-insulin ratios in human pancreatic islets. Diabetes 48:1409-1414

41. Carpentier A, Mittelman SD, Lamarche B, Bergman RN, Giacca A, Lewis GF (1999) Acute enhancement of insulin secretion by FFA in humans is lost with prolonged FFA elevation. Am J Physiol 276:E1055-E1066

42. Mason TM, Goh T, Tchipashvili V et al (1999) Prolonged elevation of plasma free fatty acids desensitizes the insulin secretory response to glucose in vivo in rats. Diabetes 48:524 530

43. Lee Y, Hirose H, Ohneda M, Johnson JH, McGarry JD, Unger RH (1994) Beta-cell lipotoxicity in the pathogenesis of noninsulin-dependent diabetes mellitus of obese rats: impairment in adipocyte-beta-cell relationships. Proc Natl Acad Sci U S A 91:10878-10882

44. Kelpe CL, Johnson LM, Poitout V (2002) Increasing triglyceride synthesis inhibits glucose-induced insulin secretion in isolated rat islets of Langerhans: a study using adenoviral expression of diacylglycerol acyltransferase. Endocrinology 143: $3326-3332$

45. Mulder H, Holst LS, Svensson H et al (1999) Hormonesensitive lipase, the rate-limiting enzyme in triglyceride hydrolysis, is expressed and active in beta-cells. Diabetes 48:228-232

46. Surwit RS, Wang S, Petro AE et al (1998) Diet-induced changes in uncoupling proteins in obesity-prone and obesityresistant strains of mice. Proc Natl Acad Sci U S A 95:40614065

47. Chan CB, De Leo D, Joseph JW et al (2001) Increased uncoupling protein-2 levels in beta-cells are associated with impaired glucose-stimulated insulin secretion: mechanism of action. Diabetes 50:1302-1310

48. Winzell MS, Svensson H, Enerback S et al (2003) Pancreatic beta-cell lipotoxicity induced by overexpression of hormonesensitive lipase. Diabetes 52:2057-2065

49. Shimabukuro M, Zhou YT, Lee Y, Unger RH (1998) Troglitazone lowers islet fat and restores beta cell function of Zucker diabetic fatty rats. J Biol Chem 273:3547-3550 
50. Mulder H, Sorhede-Winzell M, Contreras JA et al (2003) Hormone-sensitive lipase null mice exhibit signs of impaired insulin sensitivity whereas insulin secretion is intact. J Biol Chem 278:36380-36388

51. Joseph JW, Koshkin V, Zhang CY et al (2002) Uncoupling protein 2 knockout mice have enhanced insulin secretory capacity after a high-fat diet. Diabetes 51:3211-3219
52. Hosokawa YA, Hosokawa H, Chen C, Leahy JL (1996) Mechanism of impaired glucose-potentiated insulin secretion in diabetic $90 \%$ pancreatectomy rats. Study using glucagon-like peptide-1 (7-37). J Clin Invest 97:180-186

53. Ward WK, Wallum BJ, Beard JC, Taborsky GJ Jr, Porte D Jr (1988) Reduction of glycemic potentiation. Sensitive indicator of beta-cell loss in partially pancreatectomized dogs. Diabetes 37:723-729 